\title{
CAUSES AND DIRECTIONS OF CHANGES OF MEADOW-PASTURE VEGETATIONS OF THE WIELKI ŁĘG OBRZAŃSKI (WŁO)
}

\author{
AgnieszKa KlarzyŃSKa, AnNa KrysZak
}

\begin{abstract}
A. Klarzyńska, A. Kryszak, Department of Grassland and Natural Landscape Sciences, Poznań University of Life Sciences, Dojazd 11, 60-632 Poznań, Poland, e-mail: agaklar@up.poznan.pl
\end{abstract}

(Received: January 9, 2014. Accepted: February 4, 2014)

\begin{abstract}
The paper presents results of the studies conducted to determine causes and directions of transformations in vegetation of meadow-pasture communities in the area of the Wielki Łęg Obrzański [Great Obra Floodmeadows]. Multifaceted natural and habitat analyses were conducted on over 1800 relevés prepared in the vegetation seasons of 2005-2009 according to Braun-Blanquet. On their basis the phytosociological and floristic structure was analysed and habitat conditions were determined by phytoindication. Moreover, laboratory methods were applied in soil analyses to determine contents of basic macro- and microelements and groundwater table levels were recorded. Results referred to the documentation and archive literature made it possible to determine causes of transformations in plant communities in that area and outline probable directions in which succession was progressing. A lack of regular land use patterns is seen as the primary cause for the transformation in the flora of the Wielki Łęg Obrzański, particularly in the last 20 years. A considerable limitation of land use in certain sections of this area has led to the initiation of dominance of nitrophilic species such as Urtica dioica, Cirsium arvense, Potentilla anserina or Galium mollugo, while in the thinned sward it led to the development of grass species with very limited economic importance. Another equally important factor affecting the structure of vegetation cover is connected with air and water relations in soils, determined by the drainage system operating there for the last 200 years and by precipitation.
\end{abstract}

KEY WORDS: plant communities, transformations, succession, Wielki Łęg Obrzański

\section{INTRODUCTION}

A significant indicator for transformation of vegetation is provided by changes in the floristic composition and structure of phytocenoses (NösBERGER \& KASSLER 1997, KuCHARSKI 1999, KRYSZAK 2001, Zatuski 2002, Bator 2005, Krasicka-KorCZYŃSKA 2007). Numerous plant species, as well as their entire communities, are considered to be indicators of the interaction of various factors and processes, both natural and anthropogenic. Changes in the vegetation cover consist first of all in the recession of taxa with specific habitat requirements at the advantage of species with an extensive ecological scale, replacement of the species with small range limits with others - typically common, broadly distributed cosmopolitan species, colonisation of habitats of natural and seminatural communities by anthropophytes, as well as generation of inter- species hybrids (FALIŃSKi 2004). As a consequence, phytocenoses become increasingly uniform, secondary communities are formed with an impoverished floristic composition (KochanowsKa 1997, GrYNIA \& KrYsZaK 2001, Trąba 2001). Changes occurring at the phytocenose level are reflected in changes in the landscape structure. As a result of human activity hemerophobic communities recede at the succession of hemerophilic communities. The direction and intensity of occurring changes depend mainly on the degree of anthropopressure. Meadow communities being seminatural may exist and function to a considerable degree thanks to direct human activity, but their transformations result also from indirect actions (BARABASZ-KRASNY 2002, KRYSZAK et al. 2003, Aguiar 2004, PÄrtel et al. 2005). These include e.g. interference with water relations due to the construction and operation of drainage installations (Barabasz 1994, KryszaK et al. 2005) or chang- 
es in land use (i.e. intensification, extensification) (Kornaś \& Dubiel 1990, Stypiński \& Grobelna 2000, BATOR 2005).

Transformations in vegetation observed in the Wielki Łęg Obrzański have been investigated for over 50 years. Data from the 1960's (GRYNIA 1962, 1967) indicate that in the structure of the community at that time large sedge beds from the Magnocaricion alliance dominated together with variably humid meadows from the order Molinietalia, including phytocenoses with dominance of Molinia caerulea, nowadays practically non-existent.

The aim of this study was to determine causes and directions of transformations in vegetation of meadow-pasture communities in the Wielki Łęg Obrzański and to identify directions of vegetation succession.

This study constitutes a synthesis of an extensive body of results, which will be analysed in detail in further papers.

\section{RESEARCH AREA}

The Wielki Łęg Obrzański is located in the Wielkopolska Lowland, in the widest section of the Middle Obra valley, between the Southern, Central and Northern Obra Canals. It is a section of the valley which was one of the first to be drained, 250 years composed of inaccessible swamps, with dry patches found only at local sandy elevations. The floodmeadow at discharge stoppage was transformed into a lake, accumulating waters from the surrounding uplands. It is covered by deposits of fluvial accumulation overlain with a peat layer. Long-term meadow-pasture land use has shaped the present-day structure of plant communities. It varies slightly in individual canals, reflecting the effect of differing land use. Large commercial farms were situated at the Northern Canal, which is located the highest in terms of altitude, and for this reason a considerable proportion was allocated to pastures. Meadow habitats at the Southern Canal are characterised by highly mosaic patterns, with numerous interior basins and sandy elevations. Grasslands in that area are highly fragmented and have been used for years by numerous owners, similarly as it was the case at the Central Canal.

\section{MATERIAL AND METHODS}

Analyses were based on:

1. Literature data:

- characteristics of the terrain and habitat (PIENIĄŻEK 1851, MACHCZYŃSKI 1968, MACHCZYŃSKI \& ŁAWECKI 1983),

- phytosociological characteristics (GRYNIA 1962, 1967, 1996).
2. Maps:

- old German 1:25 000 maps from 1940 (3962 Kębłowo, 3963 Przemęt, 3964 Wilkowo Polskie, 3864 Wielichowo),

- military 1:25 000 maps from 1989,

- current 1:10 000 maps from 2002 (N-33-141-C-a,b,c,d Wolsztyn; N-33-141-D-a,b,c,d Rakoniewice).

3. Relevés (over 1800) prepared in the Wielki Łęg Obrzański in 2005-2009 using the classical method according to Braun-Blanquet. On their basis phytosociological structure of communities, their stability (CнміеL 1993), proportions of main geo-historical groups in the vegetation cover of the communities as well as trends in species dynamics were determined (ZARZYCKI et al. 2002). Nomenclature of species was applied following Flora Europaea (WALters \& WeBb 2001), while nomenclature of communities was adopted after the Key for the determination of plant communities of Poland (Matuszkiewicz 2008).

4. Assessment of habitats:

a) by phytoindication (Ellenberg et al. 1992) - determination of water content, soil reaction and nitrogen content in the habitat for each relevé (KLARZYŃSKA 2011),

b) determination of groundwater levels in situ, based on drillings repeated three times during the vegetation season, and organoleptic determination of soil type,

c) laboratory analyses of (KLARZYŃSKA 2011):

- organic matter contents in soil - by gravimetry,

- soil moisture content - by over-dry method,

- determination of $\mathrm{pH}$ in $\mathrm{H}_{2} \mathrm{O}$ and in $1 \mathrm{~mol} \mathrm{KCl}$ $\mathrm{dm}^{-3}$ - by potentiometry.

\section{RESULTS AND DISCUSSION}

Qualitative and quantitative transformations within phytocenoses indicate their dynamics. Particularly in previously drained areas we may currently observe rapid changes in the vegetation cover occurring under the influence of phenomena resulting from the altered system of ecological factors, e.g. muck soil formation as a result of peatbog drainage or peat mineralisation, indicated e.g. by GRYNIA (1967), OKRuszKo (1991), ILNICKI (2002), PAWLUCZUK \& GotKiewicz (2003), leading to succession of communities. Plant associations found in a given area are typically elements of one succession chain. Studies on the direction of changes occurring in the vegetation cover of meadow and rush communities have been conducted in the Wielki Łęg Obrzański for many years (GRYNIA 1962, 1967, 1996).

The primary cause for the transformations in the flora of the Wielki Łęg Obrzański, particularly in recent years, are associated with inconsistent land management. A considerable limitation of use in cer- 
Table 1. Structure of plant communities in the Wielki Łęg Obrzański

\begin{tabular}{|c|c|c|c|c|c|}
\hline \multirow{3}{*}{ Community } & \multicolumn{5}{|c|}{ Structure of plant community of Great Obra River Wetland (\%) } \\
\hline & $\begin{array}{l}\text { Great Obra } \\
\text { River } \\
\text { Wetland }\end{array}$ & $\begin{array}{l}\text { Northern } \\
\text { Obra Canal }\end{array}$ & $\begin{array}{l}\text { Northern } \\
\text { Obra Canal }\end{array}$ & $\begin{array}{l}\text { Central } \\
\text { Obra Canal }\end{array}$ & $\begin{array}{l}\text { Southern } \\
\text { Obra Canal }\end{array}$ \\
\hline & $1962 *$ & $1996^{*}$ & & 2011 & \\
\hline Phragmitetum australis & - & - & 2.5 & 0.5 & 1.0 \\
\hline Glycerietum maximae & - & 1.1 & 1.8 & 1.0 & 0.4 \\
\hline Caricetum ripariae & \multirow{4}{*}{40.0} & 2.2 & 1.3 & 2.5 & 3.5 \\
\hline Caricetum acutiformis & & - & 1.0 & 0.3 & 0.1 \\
\hline Caricetum elatae & & - & - & - & 0.7 \\
\hline Caricetum gracilis & & - & 18.2 & 9.8 & 10.6 \\
\hline Phalaridetum arundinacea & - & 12.0 & 6.3 & 4.0 & 8.2 \\
\hline Caricetum nigrae & - & - & 0.5 & - & 1.2 \\
\hline Potentillo-Festucetum arundinacea & - & 7.7 & 2.5 & 2.8 & 7.0 \\
\hline Community with Agrostis stolonifera-Potentilla anserina & - & - & 0.5 & 3.0 & 4.5 \\
\hline Community with dominance Molinia caerulea & 25.0 & - & - & - & - \\
\hline Community with Deschampsia caespitos $a=$ Deschampsietum caespitosae & 35.0 & 14.3 & 11.5 & 11.6 & 23.3 \\
\hline Cirsio-Polygonetum bistortae & - & 2.2 & - & - & - \\
\hline Alopecuretum pratensis & - & 11.0 & 5.0 & 10.8 & 1.6 \\
\hline Arrhenatheretum elatioris & - & 14.3 & 7.0 & 19.5 & 8.9 \\
\hline Community with Poa pratensis-Festuca rubra & - & - & 29.7 & 16.8 & 20.1 \\
\hline Lolio-Cynosuretum & - & 35.2 & 4.3 & 7.0 & 1.2 \\
\hline Community with Holcus lanatus $=$ Holcetum lanat $i$ & - & - & 2.8 & 2.5 & 4.8 \\
\hline Community with Anthoxanthum odoratum & - & - & - & 0.3 & 0.6 \\
\hline Community with Elymus repens & - & - & 1.8 & 5.3 & 1.4 \\
\hline Community with Bromus inermis & - & - & 1.0 & 1.3 & - \\
\hline Community with Festuca ovina & - & - & 2.0 & 1.0 & 0.2 \\
\hline Community with Lolium multiflorum & - & - & 0.3 & - & 0.7 \\
\hline
\end{tabular}

Source: GrYNIA 1962, 1996.

tain parts of the area has led to a situation when nitrophilic species such as Urtica dioica, Cirsium arvense, Potentilla anserina, or Galium mollugo start to dominate in meadows and pastures, while grasses of negligible economic role develop in the thinned sward (Deschampsia caespitosa, Bromus hordeaceus, Holcus lanatus, Anthoxanthum odoratum). In the 1960's and 1970's the lower lying areas of the Łęg were occupied by rushes from the class Phragmitetea, primarily the alliance Magnocaricion. In areas flooded for shorter periods of time communities from the order Molinietalia dominated, among which a considerable share was found for molinia meadows, i.e. 15-25\% WŁO area (GRYNIA 1962). At present molinia meadows, previously so commonly reported, have almost completely disappeared from that area, being replaced by secondary meadow and pasture communities (Table 1). Another, equally important factor affecting the structure of vegetation cover in the study area is connected with air and water relations in the soil, modified by the drainage system operating in that area for 200 years, and by precipitation (Fig. 1).

It was the aim of this study to identify probable directions of progressing succession of vegetation, while simultaneously identifying causes of changes occurring in meadow-pasture communities in the
Łęg. The model for succession of plant communities formed along individual canals was presented in Figures 2, 3 and 4. It is assumed that in the entire area of the Wielki Łęg Obrzański vegetation succession changes were progressing in a similar direction and their rate and potential occurrence of a specific link in the succession chain at a given canal were affected only by the intensity and type of land use.

The least transformed aquatic reeds and rushes of the Phragmition alliance and marsh vegetation from the Magnocaricion alliance, showing a considerable degree of naturality, are considered to be the first succession links in the study area. They currently occupy small areas, escarpments of drainage canals, deeper ditches and small basins with limited drainage. A high degree of naturality is also found for the community with Carex nigra from the class Scheuchzerio-Caricetea nigrae found in scarce interior basins.

With the lowering of the groundwater table and a shortened flooding period the rush communities start to be encroached by numerous meadow species from the class Molinio-Arrhenatheretea. These communities are mostly used as single-swath and less frequently double-swath hay meadows.

In the floristic composition of the identified phytocenoses from the class Molinio-Arrhenatheretea, mainly 


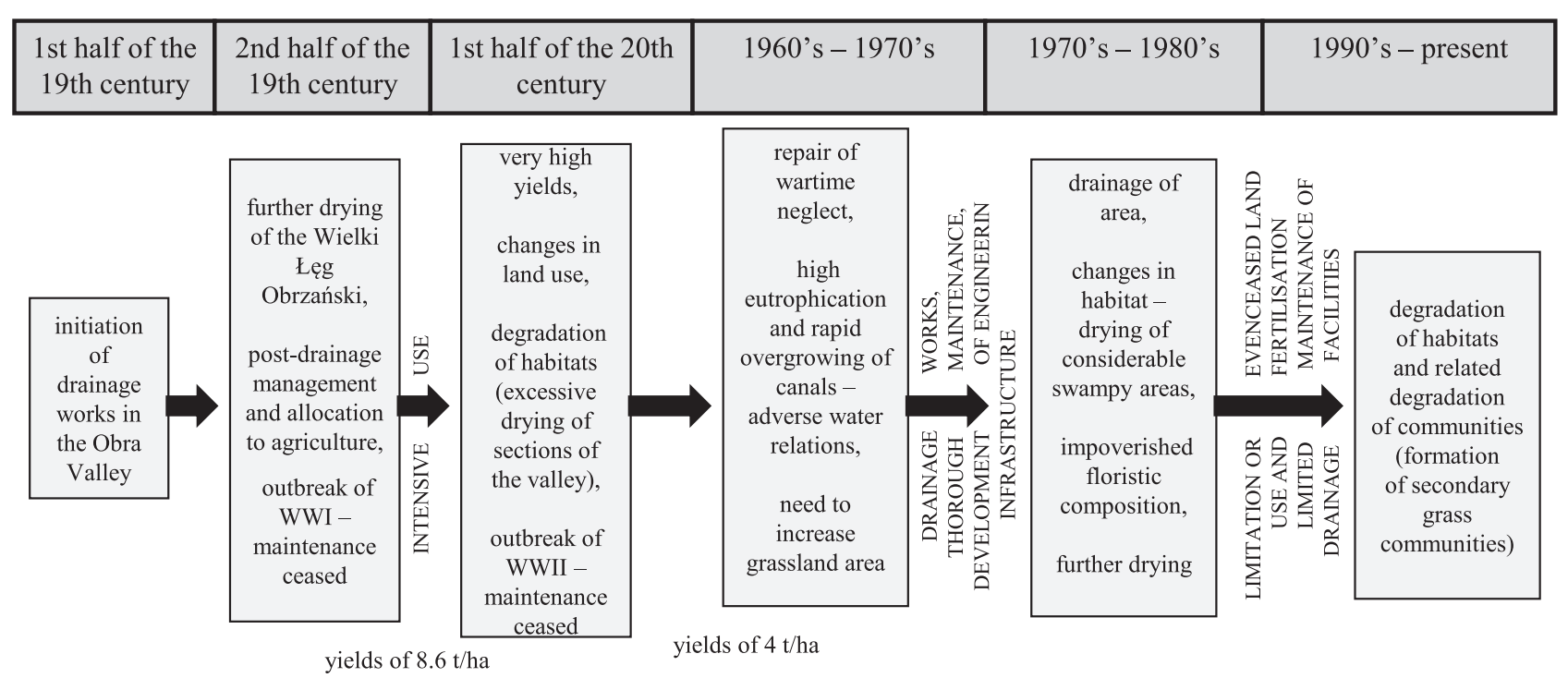

Fig. 1. Causes of changes in the structure of plant communities in the Wielki Łęg Obrzański

humid meadows of the order Molinietalia a considerable share is recorded of wet habitat species, which may indicate that they take up the position of the previously found sedge rushes. The association Alopecuretum pratensis constitutes a link between communities from the Magnocaricion alliance and hay meadows formed as a result of post-drainage management of the Wielki Łęg Obrzański in the second half of the $20^{\text {th }}$ century. Humid phytocenoses of this association in terms of their botanical composition are similar particularly to Phalaridetum arundinaceae, while in those formed on habitats with lower groundwater tables species typical of fresh meadows of the order Arrhenatheretalia. Depending on the type of land use and type of soil, the successive link in the succession chain comprised phytocenoses of Arrhenatheretum elatioris, Lolio-Cynosuretum or communities of Poa pratensis-Festuca rubra, which occupy considerable areas. Particularly the form with Festuca rubra is evidence for the extensive management in these areas in recent years. More intensively grazed phytocenoses of the community Poapratensis-Festuca rubra (mainly at the Northern Obra Canal), developed on mineral-organic soils are floristically strongly connected with the association Lolio-Cynosuretum. At increased water contents of habitats and regular mowing or grazing in bluegrass-fescue meadows, rush species, primarily Phalaris arundinacea, start to reappear, while in dried organic-mineral soils succession progresses in the opposite direction, as a variant with a considerable share of Armeria maritima and Anthoxanthum odoratum is developing.

However, currently most of the meadows previously of high economic value, as a result of inconsistently performed drainage operations, exhibit periodical water-logging, while as a result of limited use valuable fodder grass species are replaced by better adapted taxa, such as Deschampsia caespitosa, Holcus lanatus and Festuca arundinacea. Peat mineralisation and soil loosening progress more rapidly in the loosened sward. These locations are being occupied by numerous dicotyledonous plants. As a consequence of many factors, the area of the Wielki Łęg Obrzański is presently dominated by degraded forms of meadow communities. The community with Deschampsia caespitosa dominates in variably humid habitats, drier areas with muck soils are taken up by the community with Holcus lanatus, whereas small areas with mineral soils, frequently strongly dried, poor in basic nutrients, are overgrown by impoverished communities with Anthoxanthum odoratum or with Festuca ovina.

In the analysed area it is difficult to definitely identify all potential causes for transformations in vegetation and its succession interrelations, since the power of anthropogenic impact varies in practically all fragments of the Wielki Łęg Obrzański. It is determined by many different factors, starting from the habitat moisture content, through the number of cuts, grazing intensity, height of sward mowing and ending with the doses and type of fertilisation.

\section{CONCLUSIONS}

1. The currently assessed condition of vegetation in the Wielki Łęg Obrzański indicates its considerable dynamics, as manifested in the directions of succession, including:

- transition phytocenoses associated with other communities from the same phytosociological class or from other classes, and occasionally with characteristics of a fragmentary - impoverished community,

- communities formed as secondary communities: community with Holcus lanatus, community with Deschampsia caespitosa.

2. Identified communities are found on hydrogenic soils, i.e. peats, and former swamp soils. At pres- 


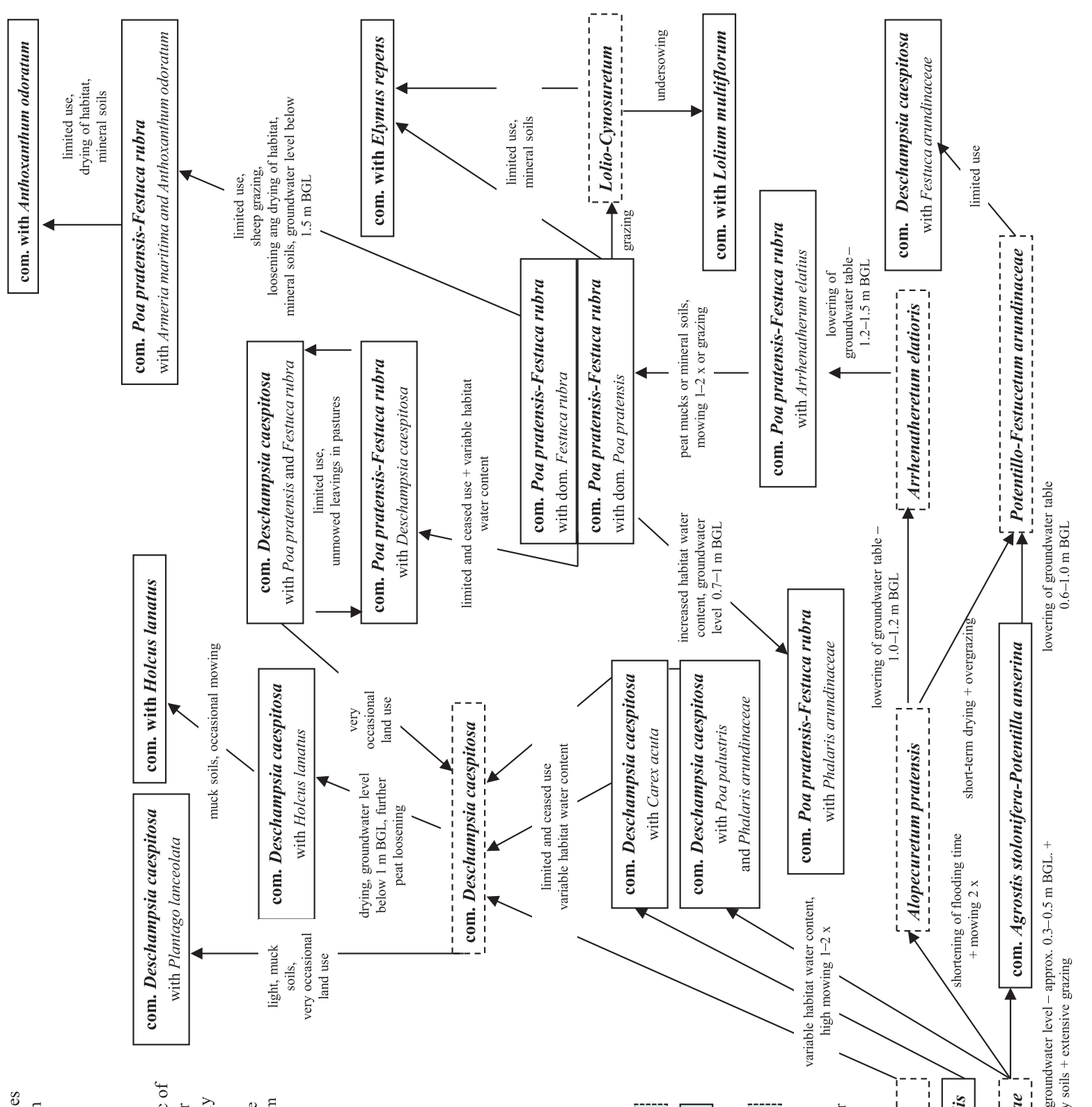

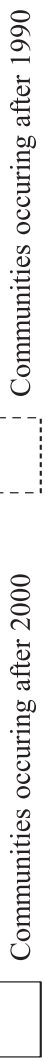

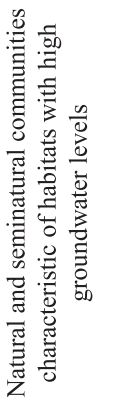
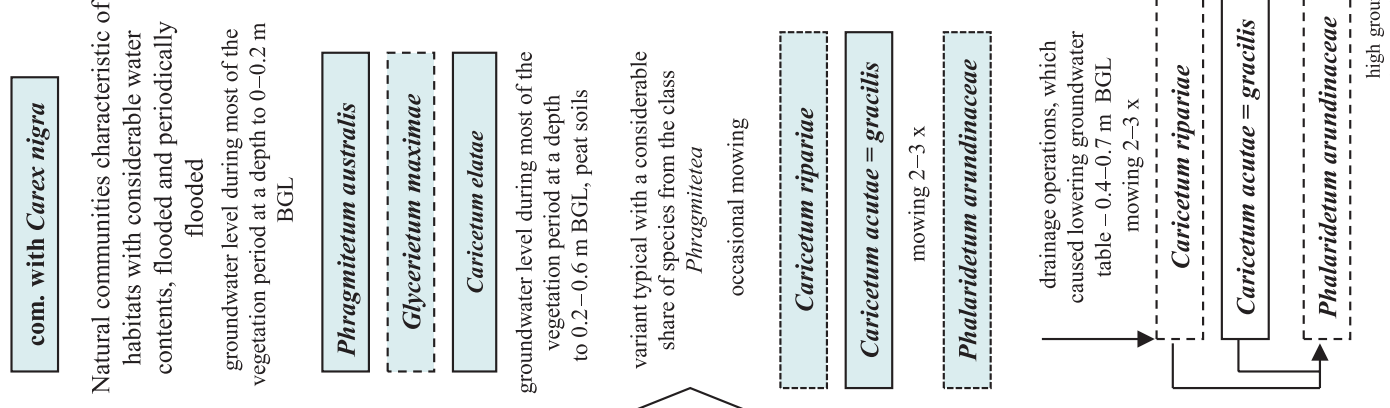

,

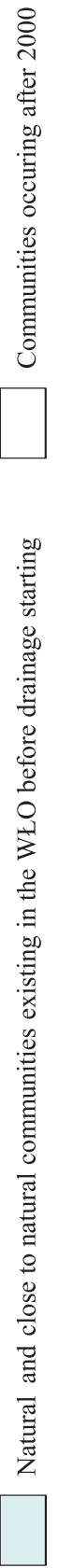

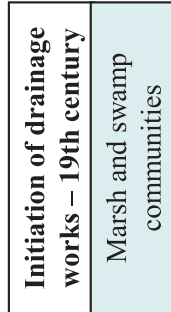

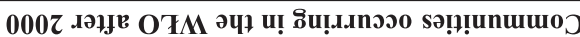

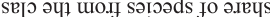

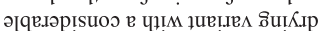

荓 

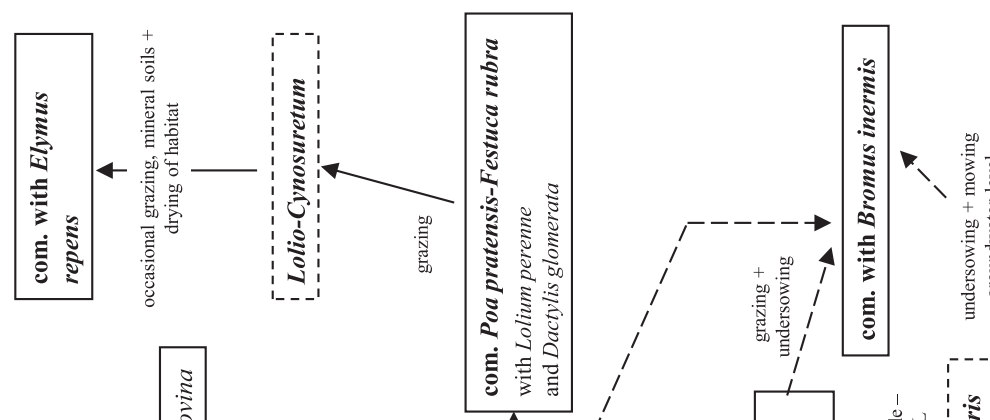

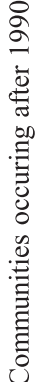
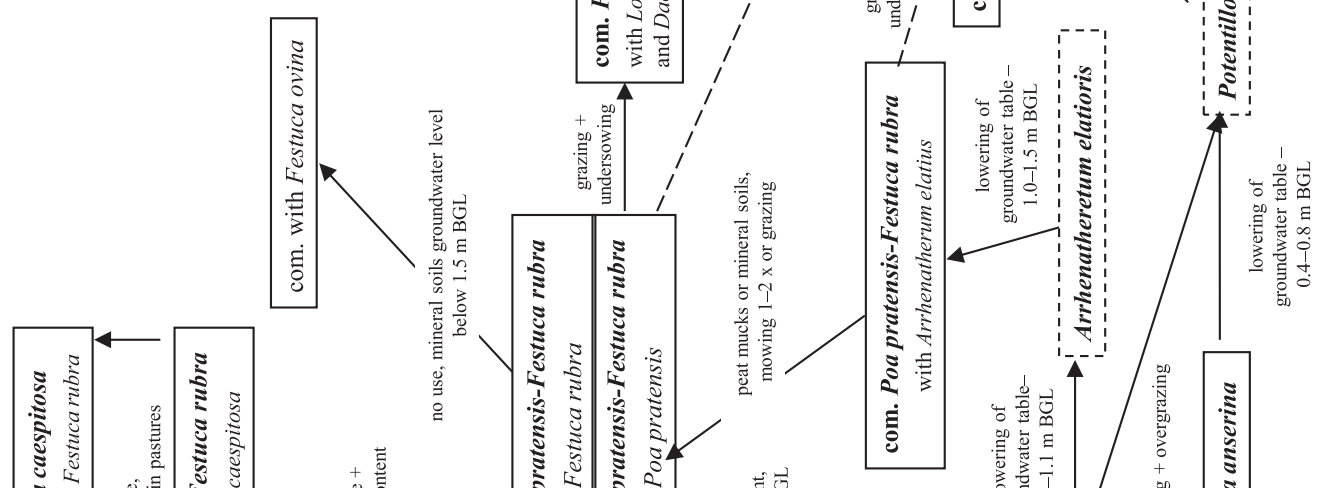

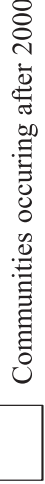
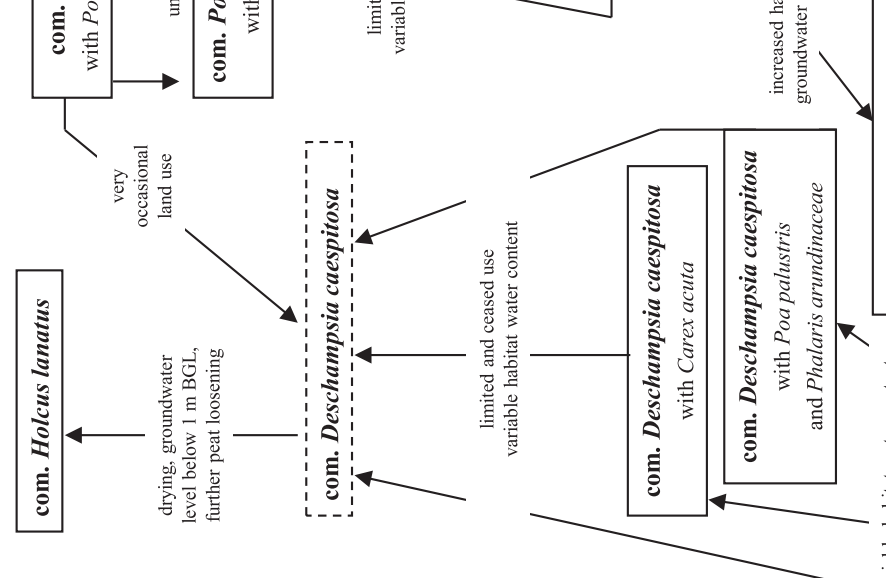

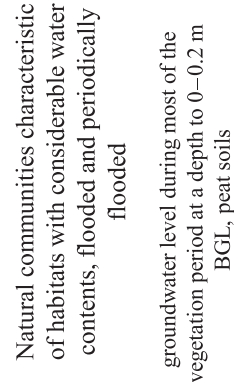
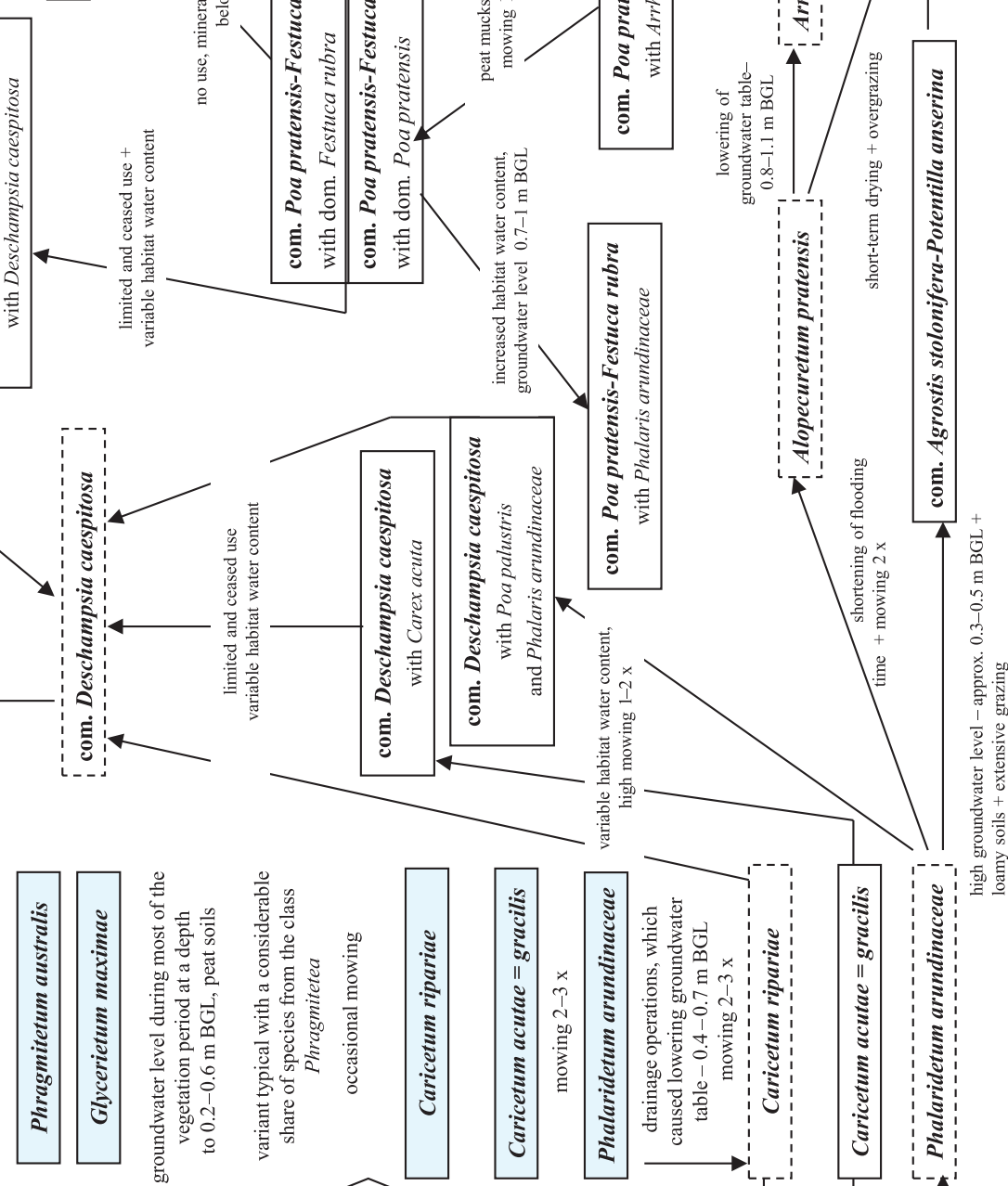


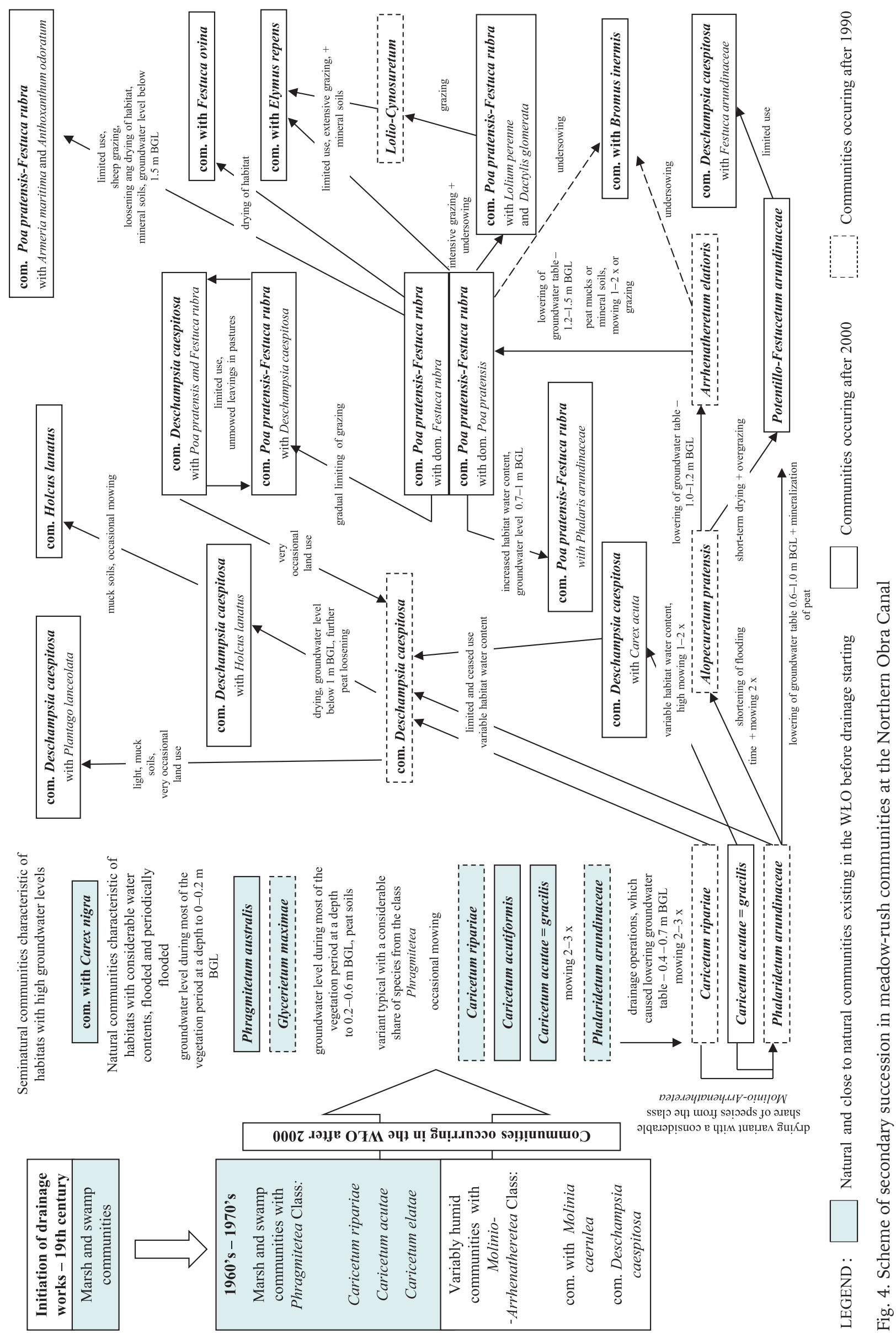


ent on these soils a considerable degree of peat muck transformation is observed, which leads to increased mineralisation of organic matter, and which is dependent mainly on the operation of the drainage system.

3. Unstable water conditions, promoting periodical flooding and limiting the performance of cultivation measures and use of meadows, resulted in the spread of the community Deschampsia caespitosa, mainly at the Southern Obra Canal.

4. The observed unstable water conditions, particularly periodical drying, contributed to the instability of many phytocenoses, manifested by:

- the presence of many species characteristic of variably humid or even drying habitats, recorded in the phytosociological structure of communities from the class Phragmitetea,

- diversification between communities of the class Molinio-Arrhenatheretea, as well as their internal structure, providing grounds for the identification of lower order phytosociological units.

\section{REFERENCES}

Aguiar M.R. (2004): Biodiversity in grasslands. current changes and future scenarious. In: S.G. Reynolds, J. Frame (eds). Grasslands: developments, oportunities, perspectives. Science Publishers, Enfield, NH, USA: 261-280.

BARABASZ B. (1994): Wplyw modyfikacji tradycyjnych metod gospodarowania na przemiany roślinności łąk z klasy Molinio-Arrhenatheretea. Wiadomości Botaniczne 38(1/2): 85-94.

Barabasz-Krasny B. (2002): Sukcesja roślinności na łąkach, pastwiskach i nieużytkach porolnych Pogórza Przemyskiego. Fragmenta Floristica et Geobotanica Polonica, Supplementum 4. W. Szafer Institute of Botany, Polish Academy of Sciences, Kraków.

BATOR I. (2005): Stan obecny i przemiany zbiorowisk łąkowych okolic Mogilan (Pogórze Wielickie) w okresie 40 lat. Fragmenta Floristica et Geobotanica Polonica, Supplementum 7. W. Szafer Institute of Botany, Polish Academy of Sciences, Kraków.

Chmiel J. (1993): Flora roślin naczyniowych wschodniej części Pojezierza Gnieźnieńskiego i jej antropogeniczne przeobrażenia $\mathrm{w}$ wieku XIX i XX. Wydawnictwo Sorus, Poznań.

Ellenberg H., Weber H., Dull R., Wirth V., Werner W., PAulissner D. (1992): Zeigerwerte von Pflanzen in Mitteleuropa. Scripta Geobotanica 18: $5-258$.

FaliŃSKi J.B. (2004): Inwazje w świecie roślin. Mechanizmy, zagrożenia, projekt badań. Phytocenosis 16 (N.S.) Seminarium Geobotanicum 10: $1-31$.
GryniA M. (1962): Łąki trzęślicowe Wielkopolski. Prace Komisji Nauk Rolniczych i Komisji Nauk Leśnych Poznańskiego Towarzystwa Przyjaciół Nauk 13(2): 145-269.

GRYNIA M. (1967): Zmiany w szacie roślinnej terenów zmeliorowanych $\mathrm{w}$ zależności od uwilgotnienia i właściwości glebowych. Zeszyty Problemowe Postępów Nauk Rolniczych 72: 181-205.

GrYNIA M. (1996): Kierunki zmian szaty roślinnej zbiorowisk łąkowych w Wielkopolsce. Roczniki Akademii Rolniczej w Poznaniu 47: 15-27.

GrYnia M., KryszaK A. (2001): Zmiany florystyczne łąk w ostatnim 30-leciu $\mathrm{w}$ dolinie Baryczy. Prace Komisji Nauk Rolniczych i Komisji Nauk Leśnych Poznańskiego Towarzystwa Przyjaciół Nauk 91: 59-66.

Ilnicki P. (2002): Torfowiska i torf. Wydawnictwo Akademii Rolniczej w Poznaniu, Poznań.

KLARZYŃSKA A. (2011): Walory przyrodnicze i użytkowe zbiorowisk łąkowych doliny Obry. Rozprawa doktorska. Katedra Łąkarstwa i Krajobrazu Przyrodniczego, UP Poznań.

Kochanowska R. (1997): Przyrodnicze konsekwencje regresu gospodarki łąkowej na Pomorzu Zachodnim. Przegląd Przyrodniczy 8(1/2): 73-76.

Kornaś J., Dubiel E. (1990): Przemiany zbiorowisk łąkowych w Ojcowskim Parku Narodowym w ostatnim trzydziestoleciu. Prądnik. Prace Muzeum im. W. Szafera 2: 97-106.

KrasickA-KorczYŃSKA E. (2007): Przemiany szaty roślinnej łąk w dolinie Noteci. Acta Botanica Warmiae et Masuriae 4: 83-93.

KRYSZAK A. (2001): Różnorodność florystyczna zespołów łąk i pastwisk klasy Molinio-Arrhenatheretea R. Tx. $1937 \mathrm{w}$ Wielkopolsce w aspekcie ich wartości gospodarczej. Roczniki Akademii Rolniczej w Poznaniu, Rozprawy Naukowe 314.

Kryszak A., Kryszak J., Grynia M. (2003): Zbiorowiska łąkowe jako wskaźnik degradacji siedlisk łąkowych. Zeszyty Problemowe Postępów Nauk Rolniczych 493: 897-904.

KrysZaK J., KryszaK A., Grynia M. (2005): Zmiany $\mathrm{w}$ siedliskach i zbiorowiskach łąkowych $\mathrm{w}$ górnym odcinku Baryczy. Annales Universitatis Mariae Curie-Skłodowska, Sectio E, Agricultura 60: 41-48.

KuchARSKi L. (1999): Szata roślinna łąk Polski Środkowej i jej zmiany w XX stuleciu. Wydawnictwo Uniwersytetu Łódzkiego, Łódź.

MACHCZYŃSKI J. (1968): Melioracje w dolinie Obry. Poradnik Gospodarski 63(80): 10, 11.

MACHCZYŃSKi J., ŁAWECKi Z. (1983): 140 lat Spółki Wodnej Melioracji Nizin Odrzańskich. Wiadomości Melioracyjne i Łąkarskie 7: 208-213.

Matuszkiewicz W. (2008): Przewodnik do oznaczania zbiorowisk roślinnych Polski. Vademecum Geobotanicum 3. Państwowe Wydawnictwo Rolnicze i Leśne, Warszawa. 
NÖSBERGER J., KASSLER W. (1997): Utilization of grassland for biodiversity. Grassland Science in Europe 2: 949-956.

OкRUszKo H. (1991): Wpływ sposobu użytkowania na glebę torfową oraz związane $z$ tym zjawiska i trudności. Biblioteka Wiadomości IMUZ 77: $105-118$.

Pärtel M., Bruun H., Sammul M. (2005): Biodiversity in temperate European grasslands: origin and conservation. Grassland Science in Europe 10: 1-14.

Pawluczuk J., Gotkiewicz J. (2003): Ocena procesu mineralizacji w glebach wybranych ekosystemów torfowiskowych Polski Północno-Wschodniej w aspekcie ochrony zasobów glebowych. Acta Agrophysica 1 (4): 721-728.

PieniążeK Cz. (1851): O bagnach nad Obrą i o projekcie ich osuszenia. Przegląd Poznański 13: 118156.

StypiŃski P., Grobelna D. (2000): Kierunki sukcesji zbiorowisk roślinnych na zdegradowanych i wy- łączonych z użytkowania dawnych terenach łąkowych. Łąkarstwo w Polsce (Grassland Science in Poland) 3: 151-157.

Trąba Cz. (2001): Tendencje rozwojowe zbiorowisk roślinnych na łąkach w dolinie Łabuńki. Łąkarstwo w Polsce (Grassland Science in Poland) 4: 189-198.

Walters M., WebB D. (2001): Flora Europaea. Royal Botanic Garden, Edinburgh.

ZAŁUSKI T. (2002): Zagrożenia i ochrona zespołów trawiastych. In: L. Frey, W. Szafer (eds). Polska księga traw. Institute of Botany, Polish Academy of Sciences, Kraków: 245-274.

Zarzycki K., TrzcińsKa-Tacik H., RóŻański W., SzeLĄG W., Wołek J., Korzeniak U. (2002): Ecological indicator values of vascular plants of Poland. (Ekologiczne liczby wskaźnikowe roślin naczyniowych Polski). W. Szafer Institute of Botany, Polish Academy of Sciences, Kraków. 